\title{
Regulation of Bile Salt Export Pump mRNA Levels by Dexamethasone and Osmolarity in Cultured Rat Hepatocytes
}

\author{
Ulrich Warskulat ${ }^{1}$, Ralf Kubitz ${ }^{1}$, \\ Matthias Wettstein ${ }^{1}$, Bruno Stieger ${ }^{2}$, \\ Peter J . Meier ${ }^{2}$ and Dieter Häussinger ${ }^{1, *}$ \\ ${ }^{1}$ Clinic for Gastroenterology, Hepatology and \\ Infectiology, Heinrich-Heine-University Düsseldorf, \\ Germany \\ ${ }^{2}$ Division of Clinical Pharmacology and Toxicology, \\ Department of Medicine, University Hospital Zürich, \\ Switzerland \\ * Corresponding author
}

The major canalic ular bile salt export pump (Bsep) of mammalian liver is downregulated by endotoxin. This study reports on the effects of dexamethasone and osmolarity on Bsep mRNA expression in cultured rat hepatocytes and its functional relevance in rat liver. Expression of Bsep mRNA in rat hepatocytes 24 and $48 \mathrm{~h}$ after isolation was dependent on the presence of dexamethasone $(100 \mathrm{~nm})$ in the culture medium. Bsep was functionally active at the pseudocanalicular membrane in cells cultured for 4 days in medium containing dexamethasone. Hypoosmolarity (205 mosmol/l) led to an induction of Bsep mRNA levels, whereas expression was decreased by hyperosmolarity (405 mosmol/l). Also the decay of Bsep mRNA following dexamethasone withdrawal was osmosensitive. In rat liver, dexamethasone counteracted the lipopolysaccharide (LPS)-induced down-regulation of Bsep mRNA levels after 12 hours and abolished the LPS-induced inhibition of taurocholate excretion. These results indicate that gluc ocorticoids are strong inducers of Bsep in liver. Furthermore, Bsep mRNA levels are osmosensitively regulated. The data suggest a longterm control of Bsep mRNA by osmolarity in addition to the short-term effects on canalicular bile acid excretion, which were reported recently.

Key words: ABC-transporter/Cell volume /

Cholestasis / Glucocorticoids / Taurocholate excretion.

\section{Introduction}

Canalicular excretion in the liver is a regulated, ATP-dependent process and requires the coordinated action of a number of ATP-binding cassette (ABC) transporter proteins in the sinusoidal and canalicular domains of the hepatocyte (Muller et al., 1997). One important member is the canalicular bile salt exportpump (Bsep), which is highly related to the $\mathrm{P}$-glycop rotein (Pgp) family and has previously been called sister of P-glycoprotein (Childs et al., 1995; Gerloff et al., 1998; Strautnieks et al., 1998). Bsep is a $170 \mathrm{kDa}$ glycosylated protein in the canalicular membrane and its full-length cDNA was isolated from rat (Gerloff et al., 1998). Tissue distribution revealed predominant expression of Bsep in the liver, where it was localized to the canalicular mic rovilli and to subcanalicular vesicles of the hepatocytes (Gerloff et al., 1998). The expression of Bsep is correlated with the differentiation of hepatocytes and is seen only in late liver development (Childs et al., 1998). Furthermore, Bsep-mediated transport rates of various bile salts followed the same order of magnitude as ATP-dependent transport in canalicular rat liver plasma membrane vesicles, i.e. taurochenodeoxycholate $>$ tauroursodeoxycholate $=$ taurocholate $>$ glycocholate (Gerloff et al., 1998). Hypoosmotic perfusion of the isolated rat liver stimulated taurocholate excretion into bile (Häussinger et al., 1992, 1993; Noé et al., 1996). Mutations in the BSEP gene are found in a subgroup of patients with progressive familial intrahepatic cholestasis (PFIC) (Strautnieks et al., 1998).

Endotoxin-induced cholestasis is mainly caused by an impaired canalicular secretion, i.e. by decreased Bsep and canalicular multispecific organic anion transporter (MRP2) levels, as well as an abnormal localization of these proteins (Trauner et al., 1997; Vos et al., 1998; Kubitz et al., 1999a). MRP2 is also regulated on a short-term basis by an osmodependent insertion/retrieval of carrier molecules into/from the canalicular membrane (Kubitz et al., 1997). Recently it was shown that MRP 2 expression is regulated by osmolarity and dexamethasone in primary rat hepatocytes (Kubitz et al., 1999b). Further, cholestasis induced by endotoxin is counteracted by glucocorticoids (Roelofsen et al., 1995; Kubitz et al., 1999a). We therefore studied the effect of dexamethasone and osmolarity on Bsep expression.

\section{Results}

Dexamethasone- and Osmolarity-Dependent Expression of Bsep mRNA in Cultured Rat Hepatocytes

Hepatocytes were grown for 12 hours in normoosmotic Dulbecco's modified eagle medium (DMEM, 305 mosmol/l) without (control) or with $100 \mathrm{~nm}$ dexamethasone or insulin. Thereafter they were exposed to anisoosmotic medium 


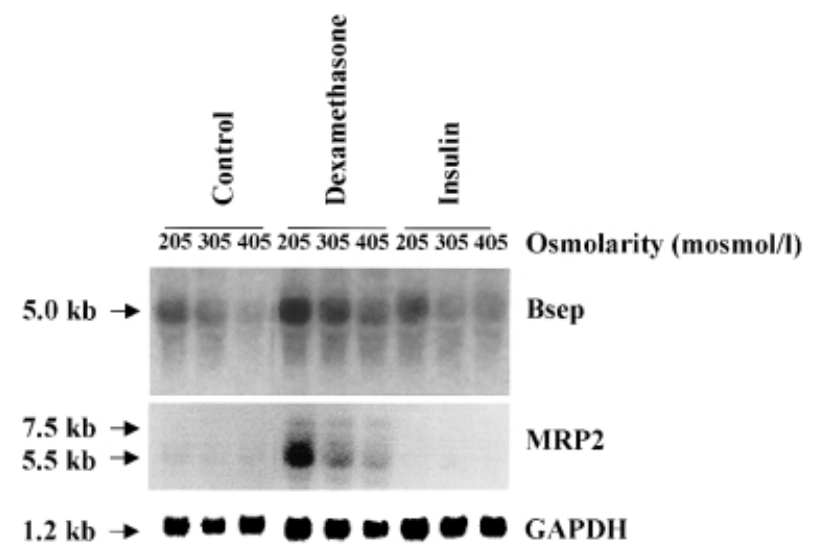

Fig. 1 Regulation of Bsep mRNA in Rat Hepatocytes by Dexamethasone and Osmolarity.

Rat hepatocytes were cultured for 12 hours in DMEM (305 mosmol//; with 10\% FBS, $100 \mathrm{~nm}$ dexamethasone or insulin), then the medium was changed to hypo- (205 mosmol/l), normo- (305 mosmol/l) or hyperosmotic (405 mosmol/l) DMEM with the same supplements. RNA was isolated after 9 hours and analyzed by Northern blotting. Dexamethasone and hypoosmotic medium increased Bsep mRNA levels, whereas addition of insulin (100 nM) without dexamethasone had no effect on Bsep mRNA levels. In contrast to Bsep, MRP 2 mRNA was only detectable when dexamethasone was present (Kubitz et al., 1999b). GAPDH mRNA was used as standard. Data are representative of 3 different experiments for each condition.

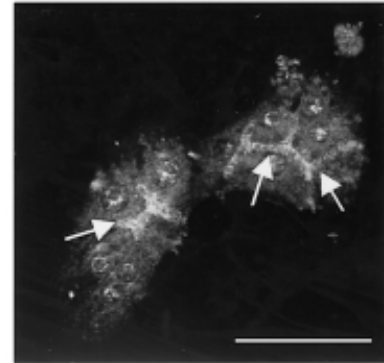

A

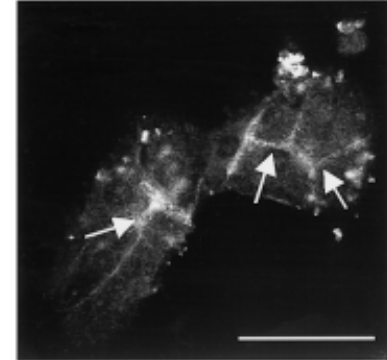

B

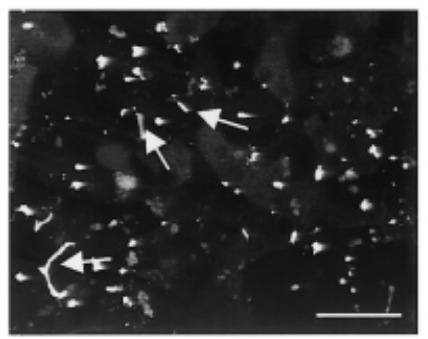

C

Fig. 2 Bsep Expression in Rat Hepatocytes Cultured with Dexamethasone.

(A), (B): Freshly isolated rat hepatocytes were cultured in DMEM supplemented with $10 \% \mathrm{FBS}, 100 \mathrm{~nm}$ dexamethasone, $100 \mathrm{~nm}$ insulin, $1 \mu \mathrm{g} / \mathrm{ml}$ aprotinin and $30 \mathrm{~nm}$ sodium selenite for 4 days. Pseudocanalicular immunoreactivity for Bsep (A) and for cell-cell adhesion molecule (C-CAM) (B) is found in these cells (see arrows). Dexamethasone-treated hepatocytes showed 15 minutes after addition of cholyllysylfluorescein $(2 \mu \mathrm{M})$ an accumulation of this Bsep substrate in the pseudocanalikuli (see arrows), indicating that Bsep is functionally active under this condition (C). Bars $=50 \mu \mathrm{m}$. (i. e. DMEM with appropriately reduced or increased $\mathrm{NaCl}$ concentration) with the same supplements for 9 hours. As shown in Figure 1, Bsep mRNA expression was dependent on the presence of $100 \mathrm{~nm}$ dexamethasone and on osmolarity of the culture medium in primary rat hepatocytes.

When Bsep mRNA levels were standardized to glyceraldehyde-3-phosphate dehydrogenase (GAPDH) mRNA there was a 10-fold difference in cells grown with $100 \mathrm{~nm}$ or without dexamethasone. Addition of $100 \mathrm{~nm}$ insulin without dexamethasone had no effect on Bsep mRNA levels (Figure 1). In line with a previous study (Kubitz et al., 1999b), MRP2 mRNA was only detectable when dexamethasone was present (Figure 1).

Furthermore, hepatocytes cultured in the presence of dexamethasone for 4 days showed a strong staining of Bsep at the pseudocanalicular membranes as demonstrated by immunocytochemical staining (Figure 2A). Compared to Bsep, a similar localized expression of rat liver cell-cell adhesion molecule (C-CAM), another canalicular protein (Lucka etal., 1995), was detected in the hepatocytes und er these conditions (Figure 2B). The functional activity of Bsep was shown by a filling of the pseudo-

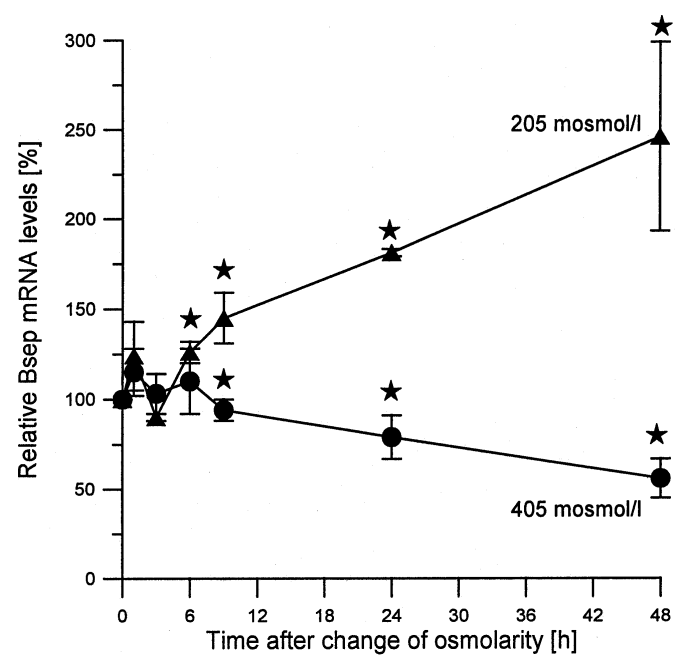

Fig. 3 Time Course of Regulation of Bsep mRNA Levels in Rat Hepatocytes by Osmolarity.

Rat hepatocytes were cultured for 12 hours in DMEM (305 mosmol//; with $10 \% \mathrm{FBS}, 100 \mathrm{~nm}$ dexamethasone, $100 \mathrm{~nm}$ insulin, $1 \mu \mathrm{g} / \mathrm{ml}$ aprotinin and $30 \mathrm{~nm}$ sodium selenite), then the medium was changed to hypo- (205 mosmol/l), normo- (305 mosmol/l) or hyperosmotic ( 405 mosmol/l) DMEM with the same supplements. RNA was isolated at the time points indicated and analyzed by Northern blots. Bsep mRNA levels were standardized by GAPDH mRNA and the relative Bsep mRNA levels found in normoosmotic incubations at each time point were set to $100 \%$ and the relative Bsep mRNA levels found in hypoosmotic ( $\mathbf{\Delta}$ ) or hyperosmotic media (-) were expressed as percentages of controls. Hypoosmotic medium increased Bsep mRNA levels after 6 hours, whereas hyperosmotic incubation significantly decreased Bsep mRNA levels after 9 hours compared to normoosmotic control. Data are given as mean \pm SEM and are from 3-4 independent hepatocyte preparations. *Significantly different from the normoosmotic incubations. 
canaliculi with cholyllysylfluorescein (Figure 2C), which is a fluorescent B sep substrate (Mills et al., 1997).

Compared to a normoosmotic control, expression of Bsep mRNA was increased under hypoosmotic conditions (i. e. when cells were exposed to medium of 205 mosmol/l) and reduced when they were kept in hyperosmotic (405 mosmol/l) medium. In contrast to MRP 2, hypoosmolarity effects on Bsep mRNA levels were already seen in the absence of dexamethasone (Figure 1). Thus, osmolarity probably modifies Bsep expression in a dexamethasone-independent way.

When the cells were grown in DMEM supplemented with $10 \%$ fetal bovine serum (FBS), $100 \mathrm{~nm}$ dexamethasone, $100 \mathrm{~nm}$ insulin, $1 \mu \mathrm{g} / \mathrm{ml}$ aprotinin and $30 \mathrm{~nm}$ sodium selenite, induction of B sep mRNA levels by hypoosmolar-

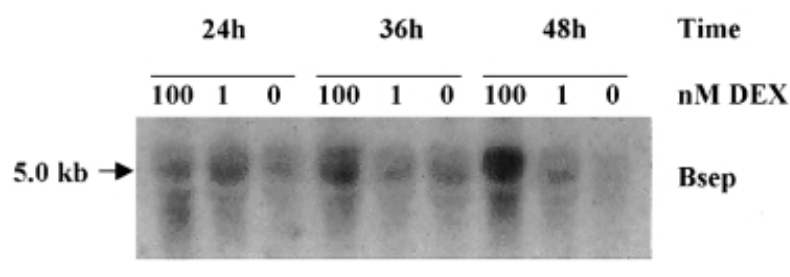

$1.2 \mathrm{~kb}$

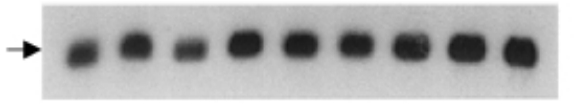

GAPDH

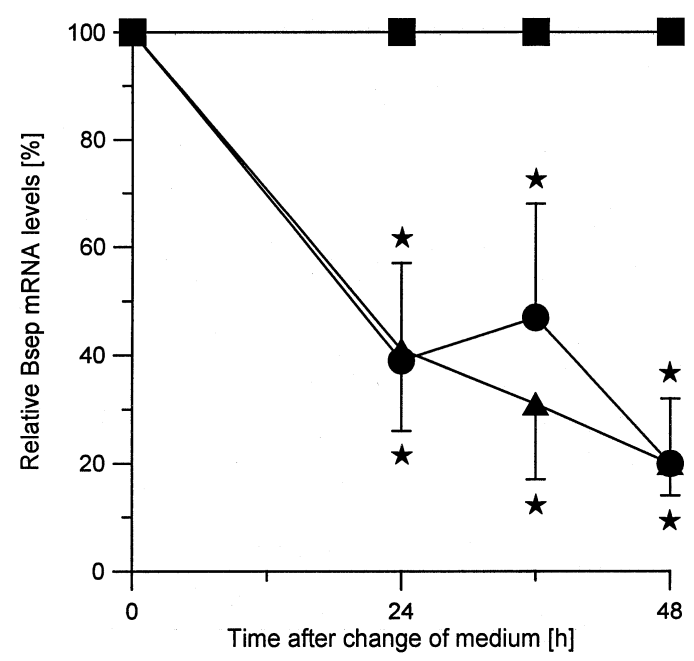

Fig. 4 Bsep mRNA Level Decreases after Withdrawal of Dexamethasone in Rat Hepatocytes.

Rat hepatocytes were cultured for 36 hours in DMEM (305 mosmol//; with FBS, $100 \mathrm{~nm}$ dexamethasone, $100 \mathrm{~nm}$ insulin, $1 \mu \mathrm{g} /$ $\mathrm{ml}$ aprotinin and $30 \mathrm{~nm}$ sodium selenite), then the medium was changed to DMEM with 0,1 or $100 \mathrm{~nm}$ dexamethasone. RNA was isolated 24 to 48 hours later and analyzed by Northern blotting. While relative Bsep mRNA levels in cells cultured in the presence of $100 \mathrm{~nm}$ dexamethasone remained relatively unchanged, a continuous decline of Bsep mRNA was observed when dexamethasone was displaced (A). Reduction of the relative amount of Bsep mRNA (B). The Bsep mRNA levels found in incubations with $100 \mathrm{~nm}$ dexamethasone at each time point were set to $100 \%$ (口) and the relative Bsep mRNA levels found in media with $1 \mathrm{~nm}(\mathbf{0}$ or without $(\mathbf{\Lambda})$ dexamethasone were expressed in relation to the dexamethasone controls. Data are given as mean \pm SEM and are from 3 independent hepatocyte preparations. * Significantly different from the incubations with $100 \mathrm{~nm}$ dexamethasone. ity was already observed after 6 hours of anisoosmolarity, whereas hyperosmotic incubation signific antly decreased Bsep mRNA levels after 9 hours compared to the normoosmotic control (Figure 3). After 48 hours anisoosmotic exposure, hypoosmolarity (205 mosmol/l) increased the relative amount of Bsep mRNA (standardized with GAPDH) by $146 \pm 53 \%$, whereas hyperosmolarity ( 405 mosmol/l) decreased it by $44 \pm 11 \%$, compared to normoosmotic incubations (mean $\pm \mathrm{SEM}, \mathrm{n}=3$ preparations).

In order to exclude the possibility that differences in dexamethasone-dependent Bsep mRNA levels were due to effects of dexamethasone on cell growth, hepatic parenchymal cells were cultured for 36 hours in DMEM supplemented with $10 \%$ FBS, $100 \mathrm{~nm}$ dexamethasone, $100 \mathrm{~nm}$ insulin, $1 \mu \mathrm{g} / \mathrm{ml}$ aprotinin and $30 \mathrm{~nm}$ sodium selenite until they reached confluence. When Bsep mRNA levels at this time point were set to $100 \%$ (=control level), expression was not significantly altered 36 hours later $(90 \pm 24 \%$ of control level, $n=4)$ but reduced to $63 \pm 32 \%$ $(n=3)$ after 48 hours. Upon lowering the dexamethasone concentration or its withdrawal Bsep mRNA levels strongly declined already within 24 hours, compared to the incubations with $100 \mathrm{~nm}$ dexamethasone (Figure 4).

The effect of anisotonicity on Bsep mRNA expression also occurred when hepatic parenchymal cells were cultured for 36 hours under this condition (Figure 5). Hypoosmolarity also diminished the decline of B sep levels following dexamethasone-withdrawal (Figure 5). These results suggest that the osmo-dependent Bsep expression may be regulated at least in part pretranslationally.

\section{Effect of Dexamethasone on LPS-Induced Decrease in Bsep mRNA Levels and its Function in Perfused Rat Liver}

In line with Vos et al. (1998), lipopolysaccharide (LPS) treatment led to a down-regulation of Bsep mRNA levels after 12 hours in rat liver, whereas Bsep mRNA levels were

100

1 0

$\operatorname{DEX}[\mathbf{n M}]$

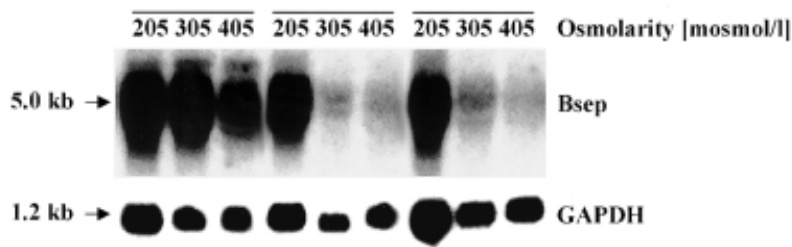

Fig.5 Osmosensitive Regulation of Bsep mRNA Levels after Withdrawal of Dexamethasone in Rat Hepatocytes.

Rat hepatocytes were cultured for 36 hours in DMEM (305 mosmol/l; with $10 \%$ FBS, $100 \mathrm{~nm}$ dexamethasone, $100 \mathrm{~nm}$ insulin, $1 \mu \mathrm{g} / \mathrm{ml}$ aprotinin and $30 \mathrm{~nm}$ sodium selenite), then the medium was changed to hypo- (205 mosmol/l), normo- (305 mosmol/l) or hyperosmotic (405 mosmol/l) DMEM with 0, 1 or $100 \mathrm{~nm}$ dexamethasone and supplements as given above. RNA was isolated 24 hours later and analyzed by Northern blots. GAPDH mRNA was used as standard. Data are representative of 3 different experiments for each condition. 


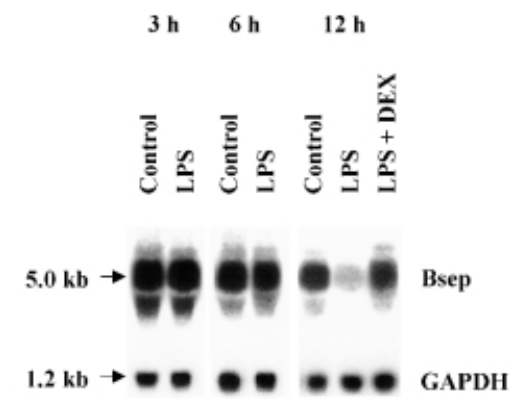

Fig. 6 Effect of LPS and Dexamethasone on Bsep mRNA Levels in Rat Liver.

Animals were pretreated by IP injection of saline (control), LPS ( $4 \mathrm{mg} / \mathrm{kg}$ body wt) or LPS plus dexamethasone ( $1 \mathrm{mg} / \mathrm{kg}$ body $\mathrm{wt}$ ). At the time points indicated, the livers were removed for RNA extraction and Northern blot analysis. GAPDH mRNA was used as standard. Data are representative of 3 different experiments for each condition.

3H-Taurocholate $100 \mu \mathrm{M}$

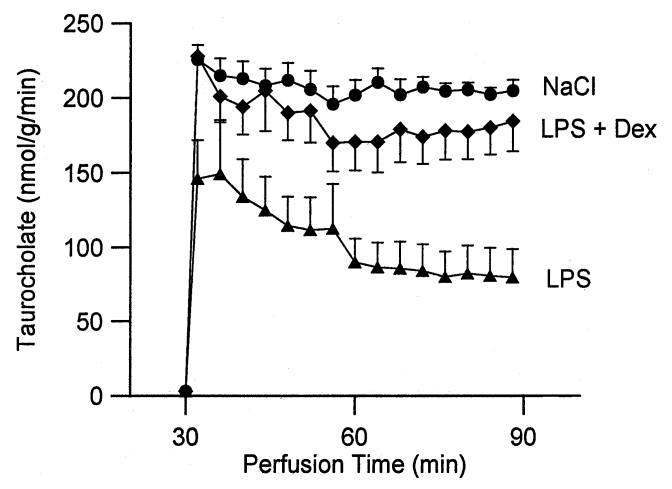

Fig.7 Dexamethasone Abolishes the LPS-Induced Inhibition of Taurocholate Excretion in Perfused Rat Liver.

Animals were injected IP with either saline (control) (' $\mathrm{NaCl}$ '), LPS (4 mg/kg body wt) ('LPS') or LPS plus dexamethasone ( $1 \mathrm{mg} / \mathrm{kg}$ body wt) ('LPS + Dex'). The livers were used for the perfusion experiment 12 hours later. LPS reduced taurocholate excretion significantly ( $P<0.05$, steady-state), whereas dexamethasone counteracted this effect. Data are given as mean + SEM and are from 4 different perfusion experiments for each condition. largely unaffected during the first 6 hours after LPS treatment (Figure 6). Interestingly, dexamethasone partially restored the Bsep and MRP2 mRNA signals (Figure 6, Table 1).

Livers from rats that received an IP injection of LPS (4 $\mathrm{mg} / \mathrm{kg}$ body $\mathrm{wt}$ ), saline (control) or LPS plus dexamethasone ( $1 \mathrm{mg} / \mathrm{kg}$ body wt) 3, 6, or 12 hours before the liver perfusion were perfused in a nonrecirculating way with a medium containing $\left[{ }^{3} \mathrm{H}\right]$-taurocholate $(100 \mu \mathrm{M})$. The steady-state taurocholate excretion into bile and bile flow were monitored by determination of $\left[{ }^{3} \mathrm{H}\right]$-excretion into bile. LPS treatment decreased taurocholate excretion into bile by $30 \pm 22 \%, 56 \pm 9 \%$, and $59 \pm 8 \%$ after 3,6 , and 12 hours, respectively ( $\pm S E M, n=4)$. As shown in Table 1 , LPS also reduced basal bile flow and bile flow in the presence of taurocholate 12 hours after injection. Dexamethasone counteracted the LPS-induced decrease in biliary excretion of taurocholate and bile flow (Figure 7, Table 1).

\section{Discussion}

This study demonstrates that dexamethasone and osmolarity regulate the expression of B sep at the mRNA level in cultured rat hepatocytes. This was observed during early culture as well as in confluent cells (i. e. after 36 hours of culture), suggesting that dexamethasone and hypoosmolarity not only stimulate Bsep mRNA expression in proliferating cells but also maintain a high Bsep mRNA level in confluent cells. As shown in Figure 2, Bsep protein was still present in the pseudocanalicular membrane of hepatocytes after 4 days of culture in medium containing dexamethasone, and functional activity of Bsep is suggested by filling of the pseudocanaliculi with cholyllysylfluorescein, which is a B sep substrate (Mills et al., 1997).

Endotoxin-induced cholestasis is probably mainly caused by decreased levels of Bsep and the canalicular multispecific organic anion transporter MRP2, as well as an abnormal localization of these proteins (Vos etal., 1998; Kubitz et al., 1999a). Bsep and MRP2 are strongly downregulated in this situation, and canalicular bile salt secre-

Table 1 Effect of Dexamethasone on LPS-Induced Decrease in Biliary Excretion of Taurocholate and Bile Flow in Rat Liver.

\begin{tabular}{|c|c|c|c|c|}
\hline & & Control & LPS & LPS +Dex \\
\hline Taurocholate excretion in bile & (nmol/g/min) & $204.9 \pm 5.3$ & $81.4 \pm 18.3^{*}$ & $178.9 \pm 16.1$ \\
\hline Bile flow basal & $(\mu \mathrm{l} / \mathrm{g} / \mathrm{min})$ & $1.28 \pm 0.16$ & $0.71 \pm 0.05^{*}$ & $1.12 \pm 0.10$ \\
\hline Bile flow in presence of $100 \mu \mathrm{M}$ taurocholate & ( $\mu \mathrm{l} / \mathrm{g} / \mathrm{min})$ & $3.26 \pm 0.16$ & $1.93 \pm 0.36^{*}$ & $2.35 \pm 0.20 *$ \\
\hline Relative Bsep mRNA levels & $(\%)$ & 100 & $42 \pm 9 *$ & \pm 25 \\
\hline Relative MRP2 mRNA levels & $(\%)$ & 100 & $12 \pm 3 *$ & \pm 22 \\
\hline
\end{tabular}

Animals were injected IP with either saline ('control'), LPS (4 mg/kg body wt) ('LPS') or LPS plus dexamethasone (1 mg/kg body wt) ('LPS +Dex'). The livers were used for the perfusion experiments and Northern blot analysis as described in Materials and Methods 12 hours later. In perfusion experiments, $100 \mu \mathrm{M}\left[{ }^{3} \mathrm{H}\right]$-taurocholate was added to the influent after approx. 30 minutes of perfusion. In Northern blot analyses, GAPDH mRNA was used for standardization. The relative Bsep and MRP 2 mRNA levels found in control rat liver were set to $100 \%$, respectively, and the relative mRNA levels found in liver from LPS or LPS plus dexamethasone treated rats were expressed as percentages thereof. LPS reduced taurocholate excretion into bile, basal bile flow, bile flow in presence of taurocholate, Bsep and MRP2 mRNA levels. Dexamethasone counteracted the LPS-induced decrease in biliary excretion of taurocholate, bile flow and mRNA levels. Data are given as mean \pm SEM and are from 4 different perfusion experiments for each condition.

*Significantly different from the control. 
tion is also reduced. LPS induced the appearance of MRP2 in intracellular vesicles in the immediate vicinity of the canaliculi within 3 hours, and these vesicles were remote from the canaliculi after 6 and 12 hours (Kubitz et al., 1999a). The LPS effects on the subcellular distribution of MRP2 and on MRP2 mRNA levels and bromosulphalein excretion were counteracted by dexamethasone (Kubitz et al., 1999a). As shown in Figure 6 and 7, dexamethasone also counteracted the LPS-induced decrease in Bsep mRNA levels and in taurocholate excretion in rat liver.

Cell swelling after hypoosmotic exposure was shown to increase the capacity of taurocholate transport into bile (Häussinger et al., 1992; Noé et al., 1996). The stimulation of taurocholate excretion by hypoosmolarity involves a $\mathrm{G}$ protein- and tyrosine kinase-dependent but protein kinase $\mathrm{C}$-independent activation of the mitogen-activated protein kinases Erk-1 and Erk-2 in hepatocytes (Noé et al., 1996). The osmotic regulation of bile acid secretion was suggested to involve the level of a dynamic equilibrium between transporter insertion into and transporter retrieval from the canalicular membrane (Häussinger et al., 1992, 1993) as shown morphologically for MRP2 (Kubitz et al., 1997, 1999a). Further, changes of the ambient osmolarity regulate MRP 2 activity on a short-term time scale by carrier retrieval/insertion from/into the canalicular membrane and by long-term effects at the level of MRP 2 mRNA expression (Kubitz et al., 1997, 1999b). These long-term effects on MRP 2 mRNA levels were dexamethasone-dependent in rathepatocytes (Kubitz et al., 1999b). However, hypoosmolarity in the absence of dexamethasone was able to induce Bsep mRNA (compare Figure 1), suggestive of dexamethasone-independent osmodependent regulation of Bsep expression. Although several osmosignalling pathways have been characterized in liver (Schliess et al., 1995; Noé et al., 1996; Häussinger et al., 1997), further studies are required to identify the precise signalling steps towards Bsep expression.

\section{Materials and Methods}

\section{Materials}

Dulbecco's modified eagle medium (DMEM, with or without $\mathrm{NaCl}$ ), fetal bovine serum (FBS) and penicillin/streptomycin were purchased from Biochrom (Berlin, Germany). Dexamethasone was from Merck (Darmstadt, Germany) and $\left[\alpha{ }^{-32}\right.$ P ]dCTP (3000 $\mathrm{Ci} / \mathrm{mmol}$ ) from ICN (Meckenheim, Germany). Insulin (bovine pancreas) and lipopolysaccharide (LPS) from Salmonella typhimurium were from Sigma (Deisenhofen, Germany). The $347 \mathrm{bp} \mathrm{cDNA-}$ probe for the rat MRP2 (Büchler et al., 1996) was a gift from Dr. D. Keppler (Heidelberg, Germany). The 1.0 kb cDNA fragment of glyceraldehyde-3-phosphate dehydrogenase (GAPDH), which was used for standardization, was from Clontech (Palo Alto, USA). The polyclonal antibody against $B$ sep was raised in a rabbit against the $C$-terminal amino acids of the rat $B$ sep sequence (Gerloff et al., 1998). The mouse monoclonal antibody Be-9.2 was raised against the rat cell-cell adhesion molecule (C-CAM) (Lucka et al., 1995) and was a generous gift from Dr. W. Reutter (Berlin, Germany). $C y 3^{\mathrm{TM}}$-conjugated AffiniPure goat anti-rabbit Ig $\mathrm{G}$ and fluorescein-conjugated AffiniPure goatanti-mouse lgG were from J ackson ImmunoResearch Laboratories (West Grove, PA, USA). The Bsep substrate cholyllysylfluorescein (Mills et al., 1997) was a generous gift from Dr. C.O. Mills (Birmingham, United Kingdom).

\section{Isolation and Culture of Rat Hepatocytes}

Isolated rat hepatocytes were prepared from livers of male Wistar rats $(150-180 \mathrm{~g}$, fed ad libitum) by collagenase perfusion as described previously (Noé et al., 1996). Cell viability was more than $90 \%$ as assessed by trypan blue exclusion. Cell purity 24 hours after isolation was approx. $99 \%$ as assessed by morphological examination. Hepatocytes were seeded in a density of $0.1 \times 10^{6}$ cells $/ \mathrm{cm}^{2}$ on collagen type VII coated 6 -well plates (Becton-Dickinson, Heidelberg, Germany). They were cultured in Dulbecco's modified eagle medium (DMEM) containing glucose (6 mM), penicillin $(100 \mathrm{U} / \mathrm{ml})$ and streptomycin $(100 \mu \mathrm{g} / \mathrm{ml})$. In some experiments the medium was supplemented with $10 \% \mathrm{FBS}$, dexamethasone (100 nM), insulin (100 nM), aprotinin ( $1 \mu \mathrm{g} / \mathrm{ml})$ and sodium selenite $(30 \mathrm{~nm})$, according to the protocols described in the Results part. Furthermore, in some experiments cells were exposed to hypoosmotic (205 mosmol/l) or hyperosmotic (405 mosmol/l) medium. Osmolarity was changed by appropriately altered $\mathrm{NaCl}$ concentration of the DMEM.

\section{Northern B lot Analysis}

Total RNA from culture plates of liver parenchymal cells in cluster 6 dishes (Costar, Cambridge, USA) was isolated by using a total RNA extraction kit (Qiagen, Hilden, Germany). Liver tissues were isolated from Wistar rats and about $1 \mathrm{~g}$ of tissue was immediately homogenized in $10 \mathrm{ml}$ of guanidinium isothiocyanate solution on ice with an Ultra-Turrax instrument at high speed. Thereafter, total RNA was isolated as in (Chomczynski and Sacchi, 1987). RNA samples were electrophoresed in $0.8 \%$ agarose/ $3 \%$ formaldehyde gels and then blotted onto Duralon-UV nylon membranes (Stratagene, Heidelberg, Germany) with $20 \times$ SSC ( $3 \mathrm{M} \mathrm{NaCl}, 0.3 \mathrm{M}$ sodium citrate). Following blotting the membranes were UVcrosslinked (Hoefer UV-crosslinker 500, Hoefer, San Francisco, USA) and observed under UV illumination to determine RNA integrity and the $28 \mathrm{~S}$ and $18 \mathrm{~S}$ rRNA bands. Hybridization was carried out with approximately $10^{6} \mathrm{cpm} / \mathrm{ml}\left[\alpha^{-}{ }^{32} \mathrm{P}\right] \mathrm{dCTP}$-labelled Bsep (Gerloff et al., 1998), MRP2 (Büchler et al., 1996) or GAPDH cDNA probes as described in (Warskulat et al., 1997). The probes were labelled by random priming under the conditions recommended by the supplier (P harmacia, Freiburg, Germany). Suitably exposed autoradiograms were then analyzed with densitometry scanning (E.A.S.Y. RH-System, Herolab, Wiesloch, Germany) to determine the optical densities of the mRNA signals. Relative mRNA levels were determined by standardization of the optical density of GAPDH mRNA.

\section{Immunocytochemistry}

For immunocytochemistry cells cultured on glass coverslips were fixed with pure methanol $\left(-20^{\circ} \mathrm{C}, 10 \mathrm{~min}\right)$. They were permeabilized with Triton-X $100(0.1 \%$ in PBS, $10 \mathrm{~min})$ and then washed with PBS. Unspecific binding was blocked with BSA ( $1 \%$ in PBS, $1 \mathrm{~h}$ ). Either a mixture of the primary antibodies (i. e. anti-rat BSEP, 1:200 plus anti-C-CAM, 1:200), PBS alone, or a single primary antibody for control staining were applied for 2 hours of incubation in a wet chamber. After rinsing and washing, a combination of $\mathrm{CY} 3^{\mathrm{TM}}$-conjugated goat anti-rabbit IgG (1:500) plus FITC-conjugated goat anti-mouse Ig $(1: 100)$ was applied for $2 \mathrm{~h}$. Finally, the cells were washed and mounted on slides. 


\section{Confocal Laser Scanning Microscopy}

Immunostained cell-samples were analyzed using a Leica TCSNT confocal laser scanning system with an argon-krypton laser on a Leica DM IRB inverted microscope (Bensheim, Germany). Images were acquired from two channels at $488 \mathrm{~nm}$ and $568 \mathrm{~nm}$ wavelength.

\section{Evidence of Functional Bsep in Rat Hepatocytes}

The transport activity of Bsep in cultured hepatocytes was assessed by the use of cholyllysylfluorescein (CLF), which is a substrate for Bsep and a us eful probe for the intracellular visualization of bile salt movement (Mills et al., 1997).

Cultured hepatocytes were grown on glass coverslips in DMEM supplemented with $10 \%$ FBS, $100 \mathrm{~nm}$ dexamethasone, $100 \mathrm{~nm}$ insulin, $1 \mu \mathrm{g} / \mathrm{ml}$ aprotinin and $30 \mathrm{~nm}$ sodium selenite for 4 days and then incubated with Krebs-Henseleit Buffer $(\mathrm{KHB})$ at $37^{\circ} \mathrm{C}$ and $5 \% \mathrm{CO}_{2}$ for 1 hour before measurement. Thereafter the coverslips were placed in a bath holder, covered with $200 \mu$ I KHB and mounted on the inverted microscope of the confocal laser scanning system. After adjustment of the optical plane, CLF (dissolved in $\mathrm{KHB}$ ) was added to the bath resulting in a final concentration of $2 \mu \mathrm{M}$ CLF. Cells were scanned every 5 minutes for 30 minutes (488 $\mathrm{nm}$ exciting light, emission measured at wavelengths $>515 \mathrm{~nm}$ ) with constant adjustments.

\section{Rat Liver Perfusion}

The experiments were approved by the responsible local authorities. Male Wistar rats (120-150 g) with free access to stock diet were injected intraperitoneally (IP) with saline (control) or LPS ( $4 \mathrm{mg} / \mathrm{kg}$ body wt) 3,6 , or 12 hours before the experiments or with LPS plus dexamethasone ( $1 \mathrm{mg} / \mathrm{kg}$ body wt) 12 hours before the experiments. Livers of injected animals were perfused in situ in a nonrecirculating system with Krebs-Henseleit buffer (305 mosmol/l) at $37{ }^{\circ} \mathrm{C}$, equilibrated with $5 \% / 95 \%$ (vol/vol) $\mathrm{CO}_{2} / \mathrm{O}_{2}$ and supplemented with $0.3 \mathrm{~mm}$ pyruvate and $2.1 \mathrm{~mm}$ lactate as described previously (Häussinger et al., 1992, 1993; Noé et al., 1996). Perfusate flow was approximately $4 \mathrm{ml} / \mathrm{g}$ liver and was kept constant throughout the individual experiment. Potassium and $\mathrm{pH}$ were monitored continuously with electrodes (Radiometer, Copenhagen, Denmark). Portal pressure was recorded using a pressure transducer (Hugo Sachs Electronics, March, Germany). Liver viability was assessed from the measurements of $\mathrm{K}^{+}$-efflux and of portal pressure. $\left[{ }^{3} \mathrm{H}\right]$-taurocholate $(100 \mu \mathrm{M})$ was added to the influent after approx. 30 minutes of perfusion. Bile ducts were cannulated and samples were collected every 4 minutes. $\left[{ }^{3} \mathrm{H}\right]$ taurocholate in bile was measured by scintillation spectrometry as described previously (Häussinger et al., 1992).

\section{Statistics}

Data were reproduced in at least 3 independent hepatocyte preparations or liver perfusion experiments. Values are expressed as means \pm SEM. Statistical analysis was performed using Student's t-Test. P values of $<0.05$ were considered to be statistically significant.

\section{Acknowledgements}

We are grateful to Prof. Dr. D. Keppler (Heidelberg, Germany), Prof. Dr. W. Reutter (Berlin, Germany) and Dr. C.O. Mills (Birmingham, United Kingdom) for provision of the CDNA probe for rat MRP2, anti-C-CAM IgG and Bsep substrate cholyllysylfluorescein. This study was supported by the Deutsche Forschungsge- meinschaft through the Sonderforschungsbereich 503 and grant Ha 1160/5-4.

\section{References}

Büchler, M., König, J ., Brom, M., Kartenbeck, J ., Spring, H., Horie, T., and Keppler, D. (1996). cDNA cloning of the hepatocyte canalicular isoform of the multidrug resistance protein, CMRP, reveals a novel conjugate export pump deficient in hyperbilirubinemic mutant rats. J . Biol. Chem. 271, $15091-15098$.

Childs, S., Yeh, R.L., Georges, E., and Ling, V. (1995). Identification of a sister gene to P-glycoprotein. Cancer Res. 55, 2029 2034.

Childs, S., Yeh, R.L., Hui, D., and Ling, V. (1998). Taxol resistance mediated by transfection of the liver-specific sister gene of P-glycoprotein. Cancer Res. 58, 4160 - 4167.

Chomczynski, P., and Sacchi, N. (1987). Single-step method of RNA isolation by acid guanidinium thiocyanate-phenol-chloroform extraction. Anal. Biochem. 162, 156- 159.

DeRijk, R., Michelson, D., Karp, B., Petrides, J., Galliven, E., Deuster, P., Paciotti, G., Gold, P.W., and Sternberg, E.M. (1997). Exercise and circadian rhythm-induced variations in plasma cortisol differentially regulate interleukin-1 beta (IL-1 beta), IL-6, and tumornecrosis factor-alpha (TNF alpha)production in humans: high sensitivity of TNF alpha and resistance of IL- 6 . J. Clin. Endocrinol. Metab. 82, 2182 - 2191.

Gerloff, T., Stieger, B., Hagenbuch, B., Madon, J ., Landmann, L., Roth, J., Hofmann, A.F., and Meier, P.J . (1998). The sister of $\mathrm{P}$-glycoprotein represents the canalicular bile salt export pump of mammalian liver. J. Biol. Chem. 273, 10046-10050.

Häussinger, D., Hallbrucker, C., Saha, N., Lang, F., and Gerok, W. (1992). Cell volume and bile acid secretion. Biochem. J . 288, $681-689$.

Häussinger, D., Saha, N., Hallbrucker, C., Lang, F., and Gerok, W. (1993). Involvement of microtubules in the swelling-induced stimulation of transcellular taurocholat transport in perfused rat liver. B iochem. J . 291, 355-360.

Häussinger, D., Wettstein, M., Warskulat, U., vom Dahl, S., Noé, B., and Schliess, F. (1997). Cell volume signalling, osmolytes and liver function. Digestion 58, 21 - 23.

Kubitz, R., D'Urso, D., Keppler, D., and Häussinger, D. (1997). Osmodependent dynamic localization of the multidrug resistance protein 2 in the rat hepatocyte canalicular membrane. Gastroenterology 113, 1438 - 1442.

Kubitz, R., Wettstein, M., Warskulat, U., and Häussinger, D. (1999a). Regulation of the multidrug resistance protein 2 in the rat liver by lipopolysaccharide and dexamethasone. Gastroenterology 116, $401-410$.

Kubitz, R., Warskulat, U., Schmitt, M., and Häussinger, D. (1999b). Dexamethasone- and osmolarity-dependent expression of the multidrug resistance protein 2 in cultured rat hepatocytes. Biochem. J . 340, 585 - 591.

Lucka, L., Cichocka, I., Bäumler, K., Bechler, K., and Reutter, W. (1995). A short isoform of carcinoembryonic-antigen-related rat liver cell-cell adhesion molecule (C-CAM/gp110) mediates intercellular adhesion: sequencing and recombinant functional analysis. Eur. J . Biochem. 234, 527-535.

Mills, C.O., Milkiewicz, P., Saraswat, V., and Elias, E. (1997). Cholyllysyl fluorescein and related lysyl fluorescein conjugated bile acid analogous. Yale J. Biol. Med. 70, 447- 457.

Muller, M., and J ansen, P.L. (1997). Molecular aspects of hepatobiliary transport. Am. J. Physiol. 272, G1285-1303.

Noé, B., Schliess, F., Wettstein, M., Heinrich, S., and Häussinger, D. (1996). Regulation of taurocholate excretion by a hypoos- 
molarity-activated signal transduction pathway in rat liver. Gastroenterology 110, 858- 865 .

Roelofsen, H., Schoemaker, B., Bakker, C., Ottenhoff, R., J ansen, P.L., and Oude Elferink, R.P. (1995). Impaired hepatocanalicular organic anion transport in endotoxemic rats. Am. J . Physiol. 269, G427- G434.

Schliess, F., Schreiber, R., and Häussinger, D. (1995). Activation of extracellular signal-regulated kinases Erk-1 and Erk-2 by cell swelling in H4IIE hepatoma cells. Biochem. J . 309, 13 - 17.

Strautnieks, S., Bull, L.N., Knisely, A.S., Kocoshis, S.A., Dahl, N., Arnell, H., and Sokal, E. et al. (1998). A gene encoding a liverspecific $A B C$ transporter is mutated in progressive familial intrahepatic cholestasis. Nat. Genet. 20, 233- 238.

Trauner, M., Arrese, M., Soroka, C.J., Ananthanarayanan, M. Koeppel, T.A., Schlosser, S.F., Suchy, F.J ., Keppler, D., and
Boyer, J .L. (1997). The rat canalicular conjugate export pump (Mrp2) is down-regulated in intrahepatic and obstructive cholestasis. Gastroenterology 113, 255- 264.

Vos, T.A., Hooiveld, G.J ., Koning, H.H., Childs, S., Meijer, D.K., Moshage, H., J ansen, P.L., and Muller, M. (1998). Up-regulation of the multidrug resistance genes, mrpl and mdrlb, and downregulation of the organic anion transporter, $\mathrm{Mrp2}$, and the bile salt transporter, Bsep, in endotoxemic rat liver. Hepatology 28 , 1637- 1644

Warskulat, U., Zhang, F., and Häussinger, D. (1997). Taurine is an osmolyte in rat liver macrophages (Kupffercells). J . Hepatology $26,1340-1347$.

Received May 31,1999; accepted September 21,1999 